\title{
Overview of challenges and achievements in the climate adaptation of cities and in the Climate Proof Cities program
}

\section{Citation for published version (APA):}

Albers, R. A. W., Bosch, P. R., Blocken, B. J. E., Dobbelsteen, A. A. J. F., Hove, van, L. W. A., Spit, T. J. M., Ven, van de, F., van Hooff, T., \& Rovers, V. (2015). Overview of challenges and achievements in the climate adaptation of cities and in the Climate Proof Cities program. Building and Environment, 83, 1-10. https://doi.org/10.1016/j.buildenv.2014.09.006

DOI:

10.1016/j.buildenv.2014.09.006

Document status and date:

Published: 01/01/2015

\section{Document Version:}

Publisher's PDF, also known as Version of Record (includes final page, issue and volume numbers)

\section{Please check the document version of this publication:}

- A submitted manuscript is the version of the article upon submission and before peer-review. There can be important differences between the submitted version and the official published version of record. People interested in the research are advised to contact the author for the final version of the publication, or visit the $\mathrm{DOI}$ to the publisher's website.

- The final author version and the galley proof are versions of the publication after peer review.

- The final published version features the final layout of the paper including the volume, issue and page numbers.

Link to publication

\section{General rights}

Copyright and moral rights for the publications made accessible in the public portal are retained by the authors and/or other copyright owners and it is a condition of accessing publications that users recognise and abide by the legal requirements associated with these rights.

- Users may download and print one copy of any publication from the public portal for the purpose of private study or research.

- You may not further distribute the material or use it for any profit-making activity or commercial gain

- You may freely distribute the URL identifying the publication in the public portal.

If the publication is distributed under the terms of Article 25fa of the Dutch Copyright Act, indicated by the "Taverne" license above, please follow below link for the End User Agreement:

www.tue.nl/taverne

Take down policy

If you believe that this document breaches copyright please contact us at:

openaccess@tue.nl

providing details and we will investigate your claim. 
Editorial

\section{Overview of challenges and achievements in the climate adaptation of cities and in the Climate Proof Cities program}

\section{Keywords:}

Climate change

City

Urban area

Vulnerability

Adaptation

Governance

\begin{abstract}
A B S T R A C T
Despite all international, national and local initiatives to mitigate climate change, a certain degree of climate change is unavoidable. Urban environments in particular seem vulnerable to the consequences of climate change. How can cities, which are dynamic systems where most people live and work, prepare for such changes in climate? In the Netherlands, the Climate Proof Cities (CPC) research program (2010 -2014) was established, aimed at: "strengthening the adaptive capacity and reducing the vulnerability of the urban system against climate change and to develop strategies and policy instruments for adapting our cities and buildings". The program has contributed to the knowledge on assessing vulnerability of cities, on adaptation options and their effectiveness, and on governance of adaptation. Important features are the role of green infrastructures in combination with available water, improved building designs and collaboration between urban planners and water managers. Nonetheless, in spite of this effort and many other national and international efforts, research in these fields is still in its infancy, and much remains to be done. The broad scope of the CPC research program incited the establishment of this Special Issue. In addition, also papers from other researchers have been added to this Special Issue, in an attempt to provide a valuable - albeit inexhaustive - view on the challenges and achievements in adaptation of cities to climate change.
\end{abstract}

(C) 2014 Published by Elsevier Ltd.

\section{Scope and motivation for a new special issue in Building and Environment on climate adaptation in cities}

Despite all international, national and local initiatives to mitigate climate change, a certain degree of climate change is unavoidable [1]. Urban environments in particular seem vulnerable to the consequences of climate change: increased risk of flooding, droughts and heat waves [2-5]. How can cities as dynamic systems, where most people live and work, prepare for such changes in climate? Research needs to strengthen the adaptive capacity and reduce the vulnerability of the urban system against climate change and to develop strategies and policy instruments for adapting our cities and buildings.

In September 2012 Building and Environment published a very successful Special Issue on "Implications of a Changing Climate for Buildings", edited by Pieter de Wilde and David Coley (Volume 55) [6]. Following this effort, a new Special Issue on climate change and cities was launched for the following reasons:

1) Attention for adaptation to the impacts of climate change is rising worldwide. Especially cities are getting organised to put climate adaptation on the political agenda. The demand for information on the impacts of climate change on cities, buildings and urban infrastructure and the effectiveness of adaptation options is growing.

2) Research on climate change impacts and adaptation in the built environment has taken off in the past few years. Whereas in first instance attention went mostly to the vulnerability of cities, more and more research nowadays focuses on adaptive solutions. Especially in the field of the (cost)effectiveness of adaptation measures rapid progress is being made.

3) In the September 2012 Special Issue, most articles focused on buildings. This new Special Issue provided an opportunity to widen the scope and to demonstrate the interrelations between adaptation in the wide range of exterior spatial scales (metropolitan, city, neighbourhood, street) and adaptation in and on buildings.

In addition, this Special Issue was incited by the end of Climate Proof Cities (CPC), a major scientific research program in The Netherlands that dealt with many of the issues related to climate adaptation in urban areas.

\section{The Climate Proof Cities program}

\subsection{Introduction}

At the end of 2010, a research program was started in the Netherlands aiming at: "strengthening the adaptive capacity and reducing the vulnerability of the urban system against climate change and to develop strategies and policy instruments for adapting our cities and buildings". The program, called Climate Proof Cities (CPC), ended in December 2014 and has been executed by a broad consortium of Dutch knowledge institutes and universities 
specialising in the field of climate adaptation and urban development, such as TNO, Eindhoven University of Technology, Delft University of Technology, Wageningen University, Deltares, Utrecht University, University of Amsterdam, Radboud University Nijmegen, KWR and UNESCO-IHE. In order to benefit from knowledge and experiences from other European countries, three foreign partners were included in the consortium: the University of Manchester (UK) and the Universities of Kassel and Freiburg (Germany).

Improving the resilience of cities requires knowledge from multiple disciplines. As adaptation to climate change is increasingly connected with and integrated in other urban design challenges, an even broader scientific basis is needed. The CPC program has included an interdisciplinary collaboration between many scientific disciplines: engineers, designers, natural scientists, spatial planners and political scientists. The research program, with a budget of about $7.8 \mathrm{M} €$, was for about $50 \%$ funded by the national government, $25 \%$ by local stakeholders and $25 \%$ by the research institutes themselves.

Involved stakeholders included the main cities in the Netherlands (Rotterdam, The Hague, Amsterdam, Utrecht, Arnhem, Nijmegen, Tilburg and Rijswijk), the Province of North-Brabant, a number of water boards (Waternet, Delfland, Hollandse Delta, Schieland and Krimpenerwaard), STOWA (Foundation for Applied Water Research) and the Netherlands national government. The stakeholders not only co-financed the program but also participated actively in formulating the research questions, exchanging experiences and delivering the case studies.

The research program addressed the following questions:

- What is the influence of urban features on the local climate in Dutch cities?

- How vulnerable are Dutch cities to climate change?

- Which measures and strategies are effective to improve the adaptive capacity of cities?

- How to implement adaptive measures in urban areas?

In the adaptation process we are facing three time and space dependent boundary conditions: (1) the extent of climate change; (2) the complex interactions between environmental, social and economic drivers of urban development; and (3) urban governance and implementation. We studied urban adaptation in this broader context in order to provide a meaningful contribution to policy making. Although urban climate, impacts, adaptation and urban governance and implementation have been studied in different work packages, we always took the larger system into account as presented in Fig. 1.

In the first work package "Urban Climate", the focus has been on measuring and modelling urban climate and the influence of weather conditions and urban features. The outcome of this work package has been used as input to the second work package "Sensitivity, impacts and vulnerability", to assess the sensitivity of cities and the possible impacts of climate change. As such, the urgency of action could be assessed. In the third work package "Adaptation measures", the effectiveness of a wide range of adaptation measures has been evaluated. The fourth work package "Governance" focused on governance of climate adaptation. Finally, in a fifth work package "Integration", the results from the foregoing work packages were assembled and applied for a number of case studies in which scientists from all work packages and stakeholders jointly designed adaptation measures and strategies. The stakeholders had a prominent place in the project.

\subsection{Stakeholder involvement}

The Climate Proof Cities research program intended to connect stakeholder issues with scientific research questions in order to

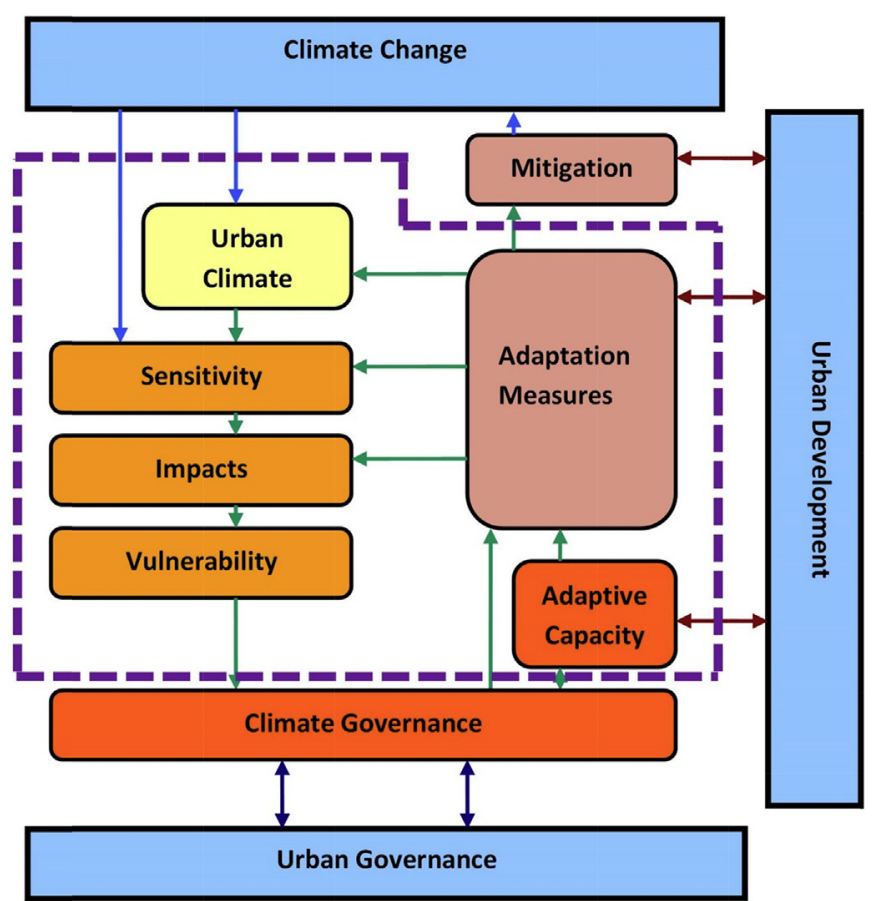

Fig. 1. Climate Proof Cities research (indicated by the dashed line) within the larger system of climate change, urban development, urban governance and climate governance.

increase the applicability of the scientific outcomes. Stakeholders were closely involved in developing the research program, formulating research questions, defining real life case studies and they were also actively engaged during the research itself. Meetings were held in the various participating cities to explore local questions and options for climate adaptation. These meetings brought a broad range of local stakeholders together from different units within the local government (spatial planning, water, environment, district councils and health services) often resulting in increased local intergovernmental cooperation.

The cases and related projects can be distinguished by four spatial scale levels: building and street, integrated water management, neighbourhood and the regional revel. The cases were located in Rotterdam, Haaglanden (comprising the city of The Hague and surrounding municipalities and water boards), Amsterdam, Arnhem, Utrecht and the province of North-Brabant, with a focus on the city of Tilburg. By meeting on a regular basis, a community of practice with researchers and stakeholders has grown where experiences and knowledge were actively exchanged.

\subsection{Main results of the Climate Proof Cities research program}

The four research questions formulated at the start of the project, provided a stable framework for the execution of the project. On the basis of these questions, results of the program will be discussed.

\subsubsection{What is the influence of urban features on the local climate in Dutch cities?}

The urban setting has an influence on the local climate. Urban land use and materials cause the urban heat island effect (UHI) [7], which might be exacerbated by climate change [8]. In the past, in many cities, research on the urban heat island effect has been performed [9]. The effect of cities on precipitation within urban areas itself however, is still relatively unknown. The availability 
of basic meteorological information within cities is limited, as weather stations are mostly located outside urban areas.

In the last 30 years, the urban climate has not been thoroughly studied in the Netherlands. Consequently, no systematic meteorological data records for cities in the Netherlands are available. Therefore, an inventory has been made of internationally available data sources and detailed temperature monitoring was done in the city of Rotterdam. In addition, the possibility of making use of alternative data sources was examined. Datasets of hobby meteorologists appeared to be a valuable source of information about local climate in urban areas. With these data a first assessment of the UHI intensity for the Dutch cities could be made. The preliminary analysis showed that the UHI is clearly present in the Netherlands as well. The maximum UHI effect ranges from 3 to $10^{\circ} \mathrm{C}$. These values are comparable with UHI values reported for other European cities. No significant relationship between UHI intensity and city size (defined as the log value of the number of citizens) could be determined, suggesting that not only large settlements but also smaller ones may show significant UHI effects [10].

In addition, the impact on outdoor thermal comfort was assessed. Approximately $50 \%$ of the urban areas appeared to be subject to heat stress for about 7 days per year. The city of Rotterdam however exceeded the heat stress threshold value for about 15 days per year [10].

Since 2009 a monitoring network is operational in the Rotterdam agglomeration, currently consisting of 14 automatic weather stations. This network enabled us to analyse the temporal and spatial variability in local climate in more detail [10-12]. Air temperatures at the urban locations in Rotterdam on average are higher than those measured at the rural reference site or at the WMO (World Meteorological Organisation) station at Rotterdam airport. The differences are larger for the minimum temperatures $(0.5-2.6 \mathrm{~K})$ than for the maximum temperatures $(-0.1-1.3 \mathrm{~K})$ [11]. The intra-urban variability is considerable, indicating that the magnitude of the UHI effect in an urban area is to a large extent determined by local features. This also explains the absence of a clear relationship between UHI intensity and city size (as defined by the number of citizens) found in previous studies $[13,14]$. This also explains why not only big cities but also smaller towns and large villages in the Netherlands display an urban heat island effect [15].

Due to a different radiation, energy and water balance, the temperature inside cities differs from the surrounding countryside [6-16]. Temperature differences are caused by (a) less ventilation [17-19]; (b) reduced evaporation and transpiration [20]; (c) enhanced release of stored heat in the urban material [19]; (d) trapping of long wave radiation; and (e) emission of anthropogenic heat [15]. Blocking wind patterns and reducing wind speed can have a detrimental effect on urban comfort $[16,17,20]$. The UHI effect depends highly on urban land-use descriptors like building fraction, impervious fraction and green fraction, as well as average building height [11]. Open water turns out to have an ambiguous cooling effect on its surroundings. When the water warms up during the summer, its cooling capacity decreases $[11,21]$.

How citizens actually perceive thermal comfort, depends on the complex interaction between physical, physiological, behavioural and psychological factors. To get an indication about the impact on thermal comfort, the so-called Physiologically Equivalent Temperature (PET) can be used, which is a measure for thermal comfort based on the energy balance of the human body [22]. It is calculated using observations of air temperature, atmospheric humidity, global radiation and wind speed. Furthermore, physiological factors are taken into account in the calculation. Compared to the surrounding areas a more limited exposure to solar radiation in the city due to shadows from buildings is favourable for thermal comfort; the lower wind speeds in the city actually have a negative effect. It is still largely unknown what role variations in atmospheric humidity play. Due to the UHI effect, Dutch urban areas experience more days of heat stress than in the countryside [11].

In order to have an indication of the urgency of the heat stress problem in relation to climate change, the temperature sequences of the urban location in southern Rotterdam and the reference location in the countryside have been transformed into temperature sequences for 2050 and 2100 for the worst case scenario (W+) developed for The Netherlands by the Royal Netherlands Meteorological Institute - KNMI [23]. Because PET could not be calculated from the results provided by this transformation program, we made estimations of the Effective Temperature (ET), a simple thermal comfort index based on empirical research [23]. It is assumed that water vapour pressure and wind speed remain similar. Fig. 2 shows the number of days that the discomfort threshold is exceeded $\left(\mathrm{ET}>21^{\circ} \mathrm{C}\right)$. Though only rough estimates could be made, it clearly indicates that heat stress may become an important issue in the coming decades.

\subsubsection{How vulnerable are Dutch cities to climate change?}

The possible impacts and sensitivity of cities to the various influencing factors were studied. A wide range of effects was considered related to more frequent weather extremes such as heat waves, extreme rainfall and to a lesser extent periods of drought. Concerning heat waves, both outdoor and indoor effects were studied. Although these issues are often related to climate change, already at this moment cities cope with the impacts of these kinds of weather events. The risks of coastal and fluvial flooding of urban areas due to sea level rise and changes in the flood water levels in the rivers together with the consequences of soil subsidence [24] were outside the scope of the Climate Proof Cities program.

The risk of more frequent heat waves, droughts and extreme rainfall events are severe as they affect morbidity and mortality, economic damage and result in lower liveability and comfort in the urban environment. Some impacts cause damage (for instance to building materials or properties in case of flooding), while others influence health and well-being of the population (for instance in heat waves) [24].

A quantification of sensitivity, the impacts and the resulting vulnerability is necessary for providing guidelines for adaptation solutions, for the mapping of vulnerability of neighbourhoods and prioritisation of measures [25]. As impacts differ, such a quantification needs to be made at various scales: from the level of buildings, in terms of heat, moisture or salinisation impact, to the level of

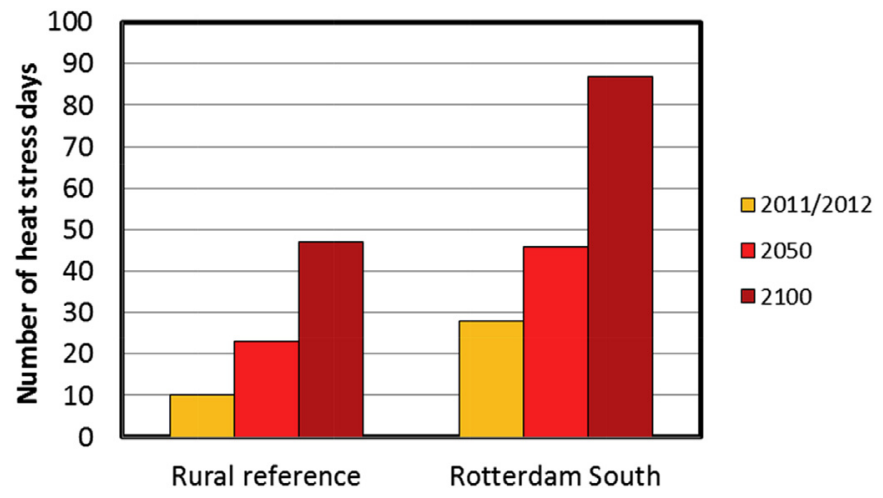

Fig. 2. The number of days with moderate to high heat stress for two locations: the countryside (left) and 'Rotterdam South'(right), calculated for the current situation, halfway through this century, and at the end of it with the (W+) KNMI'06 scenario.[23]. 
neighbourhoods and cities for impacts of flooding, droughts and heat waves. A typology of cities and neighbourhoods according to their vulnerability to climate change summarising this information is a useful tool to enable policy makers to judge the urgency of action and to prioritise between areas and possible measures [26].

2.3.2.1. Heat stress. The hot summers in 2003 and 2006 demonstrated that the Netherlands are vulnerable to heat waves. In the Netherlands the death rate increased by $12 \%$ during heat waves (approximately 40 extra deaths per day) [27,28]. The 2003 heat wave caused approximately $1400-2200$ deaths [28], similar to other European countries as France and Britain [29]. Climate change scenarios assume that the number of tropical days, as they are called in the Netherlands (air temperature above $30{ }^{\circ} \mathrm{C}$ ) can increase from an average of 4 in the period 1976-2005 to $7-15$ in 2050 [30]. The elderly over the age of 75 are especially sensitive to periods of heat stress [31]. In the Netherlands, during the 2010 heat wave, body temperatures of elderly exceeding $38{ }^{\circ} \mathrm{C}$ were measured during the day [32], illustrating the heat strain during hot days. In an attempt to study whether they would be able to prepare for an approaching heat wave in a climate test chamber, it emerged that the typical warning period of three days prior to a heat wave is too short for both young people and the elderly to acclimatise [33].

Labour productivity will also decrease in conditions with high (above $25{ }^{\circ} \mathrm{C}$ ) indoor and outdoor temperatures [34]. An exploratory calculation of the monetary damage in the Netherlands caused by lower productivity inside non-air-conditioned buildings and outside buildings amounted from zero to several hundreds of millions of euros per year depending on the climate scenario [24].

Buildings can decrease the exposure to heat. Unfortunately it turns out that, based on the KNMI'06 climate scenarios [23], overheating (indoor temperatures higher than the threshold values for thermal comfort) will be more frequent and will last longer in a large proportion of Dutch buildings. Our simulations with building energy models demonstrate that terraced and detached houses are expected to be less often exposed to high indoor air temperatures and experience fewer hours of overheating than apartments (Fig. 3) [35]. In addition, the building orientation is an important factor; windows on the east and the west side increase the number of overheating hours, because of the lower elevation of the sun during summer time allowing more incoming solar radiation. Furthermore, modern, and thus better insulated houses (without sunscreens), are more sensitive to indoor overheating than older

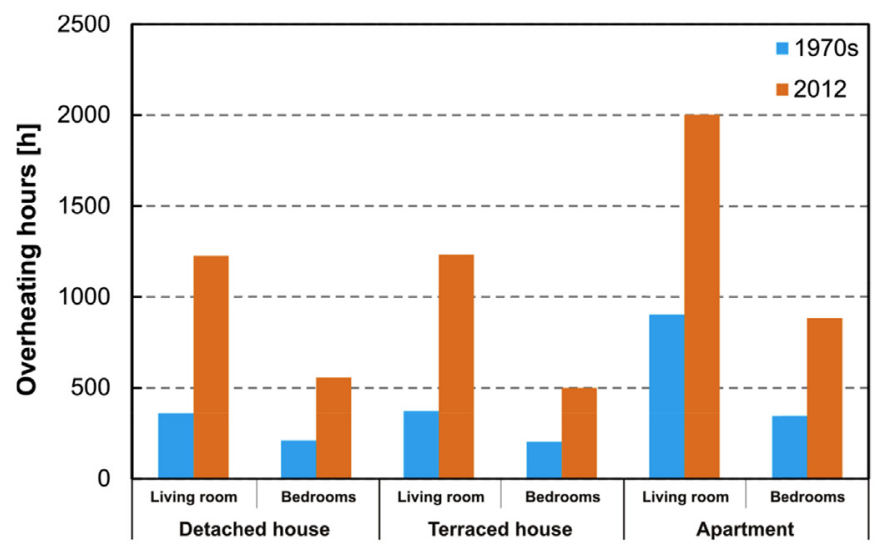

Fig. 3. Yearly number of overheating hours (averaged over four orientations) for three types of houses and two different construction years (1970s and 2012). The climate year used for this study is 2006 in De Bilt, the Netherlands, which is a year that can be seen as a "future year" with a hot summer containing several heat waves.[35]. dwellings since they retain the heat for a longer period due to their higher thermal resistance of the building envelope (Fig. 3) [35].

Information about the location of sensitive groups, such as the elderly, has been combined with their living conditions (quality of housing and neighbourhood characteristics as measure for exposure). The result is a vulnerability map (Fig. 4) [36]. The map indicates which parts of the city are vulnerable to heat stress. For Amsterdam, it turns out that areas for special attention are the western part of the city, but also the north, east and southeast. This map also depicts a considerable small-scale variation in vulnerability within Amsterdam: to the large local variation in the UHI effect depending on local structural characteristics, other sources of diversity (population characteristics, building quality) are added [36].

2.3.2.2. Pluvial flooding. Objects that are particularly sensitive to material damage due to pluvial flooding are buildings (and their interiors) and electricity switch boxes. Substantial secondary economic damage can also occur through business interruption, traffic disruption and power and telecom/data cuts. In addition there are costs for mobilising emergency services and there are social implications if hospitals etc. function below par or are less accessible. Risks and damage due to extreme rainfall are generally dependent on a threshold value that differs per object, for instance, the height at which switch boxes are mounted. Decreasing exposure during extreme rainfall can be achieved locally by ensuring that the water remains below the threshold value (by increasing storage area and infiltration) or by increasing the threshold value (for instance higher doorsteps, mounting switch boxes higher up) [24]. Even more than the exposure to heat stress, the exposure and the vulnerability to the effects of pluvial flooding displays a fine spatial pattern [37].

2.3.2.3. Drought. Periods of drought causing a decrease in the ground water level can be very harmful to the wooden foundation piles of old buildings as they decay under regular exposure to oxygen [38]. Another effect of sea level rise is the extension of the seepage of salt water into the ground water in a small strip along the coast [39], although this was not studied in the Climate Proof Cities research program.

\subsubsection{Which measures and strategies are effective to improve the adaptive capacity of cities?}

To support decision makers, the CPC program has delivered lists of possible adaptation measures and their characteristics with regard to applicability in various situations. In addition, measurements, numerical simulations and street interviews have been carried out to gain insight into the effectiveness of individual adaptation measures and combinations of measures for different spatial scales. The numerical simulations were based on BES and CFD. BES has been used extensively in the past in building physics for the assessment of energy and thermal comfort inside buildings (e.g. literature reviews/overviews in Refs. [40-43]). In the CPC program, it was used to analyse indoor overheating during heat waves [35]. CFD has been used extensively in the past in urban physics and building physics to analyse indoor (e.g. literature reviews in Refs. $[43,44])$ as well as outdoor airflow, heat and mass transfer (e.g. literature reviews in Refs. [45-50]). In the CPC program, it was used to analyse heat waves, the UHI effect, outdoor thermal comfort and the potential of adaptation measures such as vegetation and evaporative cooling [20,51-53]. This knowledge will be translated into design guidelines in the final year of the program (see e.g. Ref. [51]). Building on the conclusion that vulnerability in Dutch cities displays a spatially varied pattern, decreasing this vulnerability will also requires interventions at different spatial scales or levels. 


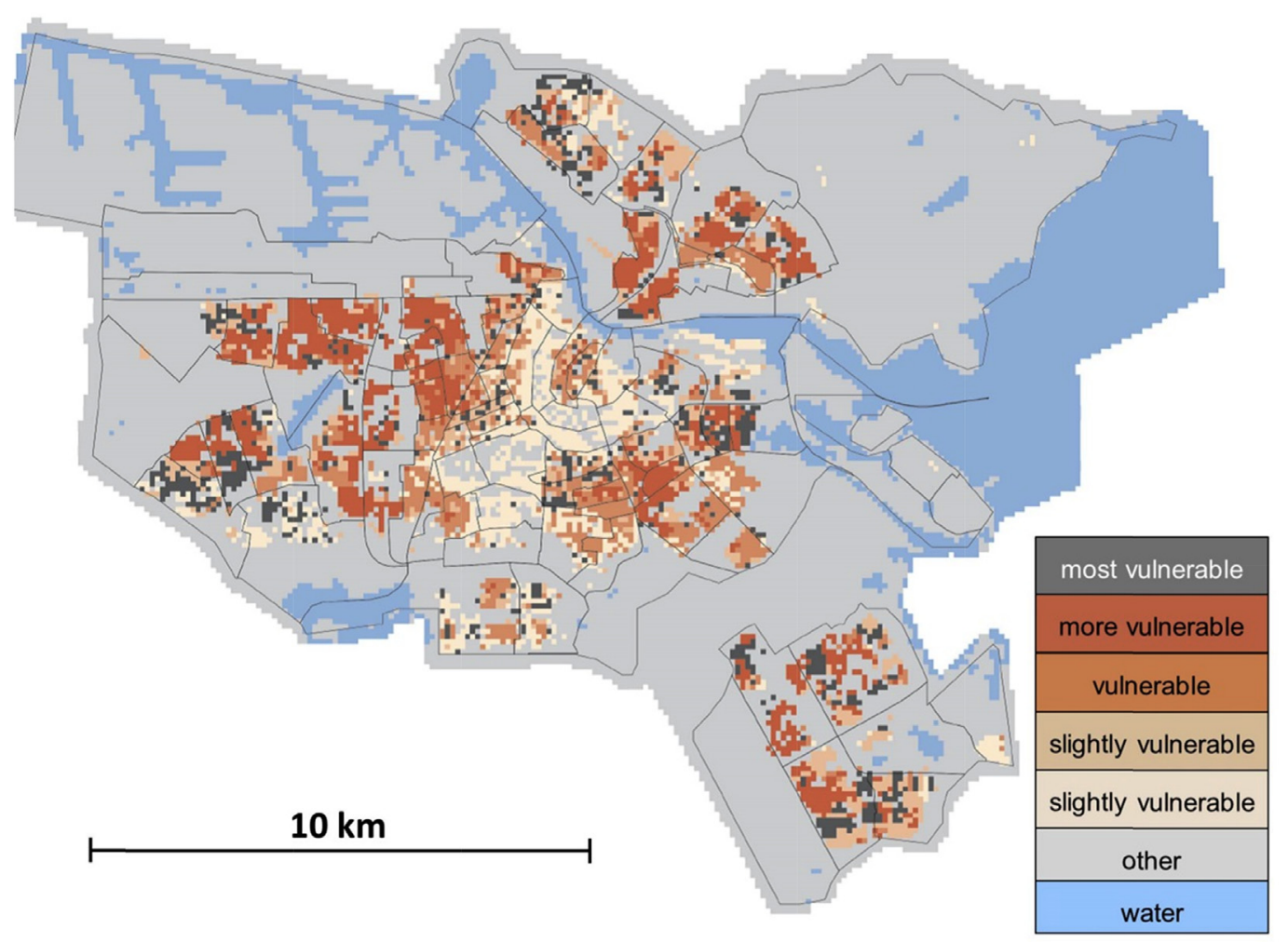

Fig. 4. Vulnerability map of inhabitants of Amsterdam with respect to heat stress [36].

The research on adaptation measures has focused on three main spatial levels:

- buildings and street-level components that will be able to cope with altered heat stress and more precipitation extremes whilst reducing the demand for energy and improving indoor air quality;

- neighbourhood level: providing design guidelines for layout, use of materials, green spaces and water;

- the region around cities for providing the buffer against extremes in heat, drought and precipitation.

2.3.3.1. From building to street. In the prevention of indoor overheating a distinction can be made between the effect of adaptation measures on new and existing residential buildings. Building Energy Simulations for a terraced house show that newly constructed (well insulated) residential buildings benefit most from avoiding solar radiation through the transparent parts of the building envelope (e.g. doorways and windows) and from providing additional natural ventilation by strategically and systematically opening windows (i.e. (night) ventilative cooling) [35]. Note that the application of solar shading and opening the windows quite often require actions from the building occupants and therefore the effectiveness in practice will be strongly depend on user behaviour and knowledge of the user on how to prevent indoor overheating. Although the application of extra thermal insulation is essential to reduce energy demands for heating in the winter, providing extra thermal insulation can have a negative effect on indoor thermal comfort in older and new houses when no solar shading or sufficient natural ventilation is present. Increasing the shortwave reflectivity (albedo value) can reduce the number of overheating hours in older houses significantly (up to $89 \%$ for a detached house), but has far less effect on the number of overheating hours in modern - well-insulated - houses. In addition, a building's orientation is an important factor in reducing the number of overheating hours in residential buildings. As has been mentioned above, in the summer months, but also in spring and autumn, houses facing east and west experience the largest numbers of overheating hours due to the lower solar elevation (zenith angle). A residential building with a larger amount of thermal mass can reduce the peak temperatures inside the building during the day, however, a larger amount of thermal mass can also result in a slower decrease of indoor temperatures during the night, potentially resulting in more overheating hours during the night [35].

To intercept and store rainwater, several options are available in and around buildings, including creating water storage in the spaces below and between buildings, green roofs, "blue roofs", water barrels, infiltration boxes, bioswales and permeable pavement [54]. Green roofs appear less effective as it takes longer to have the full capacity available for the next rain shower [54]. Moreover, they are more expensive than blue roofs, i.e. roofs that are able to store rainwater and gradually discharge it, but in comparison to blue roofs, green roofs can be applied on slightly sloping roofs. Also, research in the CPC program has shown that the effects of locally applied green roofs on reducing both indoor and outdoor temperatures are very limited [20]. Concerning rainwater, in the Netherlands, specific attention is given to removing pavement from gardens or preventing gardens to be paved.

The effectiveness of packages of these adaptation measures on occurrence and extent of flooding can now be assessed and visualised in 3D during the design process by a new, very fast hydraulic simulation programme called 3Di (www.3Di.nu/international/), which development was partially funded by the CPC programme. Stakeholders can co-design their preferred adaptation solutions for a specific area by combining 3Di with an electronic touch or design table. 
2.3.3.2. From street to neighbourhood. Measures that effectively lower the temperature of the air at street level in the Netherlands are: increasing the reflection coefficient (albedo) of the roof and adding vegetation (gardens, street trees and parks).

In parks, ambient temperatures were measured that were $1 \mathrm{~K}$ lower than in the city centre, with PET values being $1.9 \mathrm{~K}$ lower than in the city centre [55]. CFD simulations demonstrated that rows of trees in streets can have a similar effectiveness, but that green facades and green roofs have little influence on ambient temperatures on street level [20]. The results are in line with the international literature, where similar effects were reported [56-59]. In addition, it turns out that people feel more thermally comfortable in streets with a lot of greenery and also appreciate it from an aesthetic point of view [60].

More drastic, technical measures that could enable control over the city's climate are forms of active cooling of open water and public spaces such as squares. Taking away (solar) heat from these surfaces and storing it inter-seasonally underground - for instance by means of aquifer thermal energy storage (ATES) - helps to cool the city in summer, and the energy stored can again be used in wintertime [61]. Here climate adaptation touches climate mitigation. Another option is evaporative cooling by mist spraying nozzles (e.g. Ref. [52]).

In order to make the urban water systems stronger with respect to pluvial flooding, many measures are available to increase the infiltration, storage or transport capacity, both above and below ground level [54]. Several measures for adapting to pluvial flooding, however, can lead to an increase of drought and heat stress. An integrated approach is therefore necessary. An application has been developed in CPC, which is known as 3Di, which gives insight into the effects of adaptation measures in water management and spatial development. As such, the instrument brings urban planners and water managers together in identifying measures for dealing with cloudbursts.

2.3.3.3. From neighbourhood to urban region. The climate in a city is partially determined on a scale that supersedes individual buildings, streets and neighbourhoods. If air could be drawn into cities from surrounding areas that are cooler than the city itself, excessive heating in summer could be tempered. Therefore research has been carried out on so-called 'coolspots' near cities. The first results indicate that much of the surface area in 'coolspots' is taken up by vegetation and that they are usually in use as meadows or fields. The soil type also seems to be an important aspect of 'coolspots', while the ground water level does not seem to play an important role.

\subsubsection{How to implement adaptive measures in urban areas?}

Implementing climate adaptation measures and strategies is a challenging task for city governments. Within the frame of urban planning, increasing resilience is one of many interests. As climate adaptation appears to have small economic benefits in the short term, it is generally a weak interest, with low political standing, especially when extra costs are involved. Only after incidents occur, climate adaptation can temporarily get a much higher priority.

However, if a carefully laid out strategy in stages is accompanied by support from higher tiers of government, this position can change significantly. As ideological arguments (with a weak economic impact) are more successful on higher administrative levels of government, it should be possible to arrange support there. This support is needed to overcome existing (and new) barriers towards adaptation at lower tiers of government, where pragmatism rules. Although this road may appear a tedious one, it is nevertheless an exciting challenge in which both practitioners as well as scientists can play an important role.
The research focussing on municipalities has shown two successful approaches so far: 'mainstreaming adaptation' and a 'dedicated approach'. The mainstreaming approach aims to integrate climate adaptation into existing policy domains - such as planning, public space, housing and water management - in order to find synergies by policy synchronisation and combining resources [62]. A dedicated approach poses climate adaptation as a new policy domain, including agenda-setting, financial and human resources allocated to adaptation-related actions and consistency in policy [63]. Both have positive and negative consequences. A dedicated approach entails that decisions are made quickly, but there is also a risk of inefficient policy. On the other hand, mainstreaming is often ad hoc but based on well-considered decisions. A combination of both can conceivably lead to more optimal results [64].

It has also turned out that citizens can play a role in the realisation of the climate proof city. To be able to link the climate interests of public parties to civilian initiatives, the local government should find a new way of working. This requires a flexible attitude, where local government policy adapts to local initiatives (co-evolution) [65].

The same holds for the development of housing, whereby housing corporations and the construction industry together can be made responsible for constructing or renovating climate resilient housing. In this model, the construction industry does not limit itself to carrying out the corporation's commission, but has a more active role in the initial stages. In this way, the knowledge of the construction companies is used in the process, which makes it easier to realistically integrate climate proof measures in the construction process [66].

Integrating climate adaptation in the development of an area within the city brings all these aspects together. Science provides the tools for analysis, communication and dialogue: "indicators" in order to show the consequences of climate change for a city; "mapping" of exposure, sensitivity and adaptability in order to discover the vulnerability in detail; and "tables and diagrams", as a basis for choosing adaptation measures. In the Bergpolder Zuid district in Rotterdam, the Netherlands, these were the basis for sourcing different types of knowledge (research, societal groups, policy makers). In a sketching workshop these were integrated and translated into policy recommendations [67]. In these exercises it appeared that a cost-benefit analysis for adaptation is not always important as decision support tool. For an area-specific approach, where the emphasis lies on co-benefits, it is no longer strictly necessary to have a breakdown of the specific costs of climate adaptation and the specific climate benefits. Nevertheless, an overview of possible damages due to climate change is seen as motivating in order to draw attention to climate adaptation, but it is often difficult to calculate (data intensive, with not all data available at the appropriate scale). In the implementation stage, of course, for each policy decision information is needed about the overall costs that specific course of action entails.

\subsection{Discussion}

Cities and urban areas are often seen, contrary to nature, as places where people are in complete control and independent of the whims of nature, such as weather and climate. That is not true as every now and then is shown by (small) disasters resulting from heat waves, heavy rainfall and long periods of drought. At the moment these are incidents. However if the climate continues to change, extreme weather events may occur more often and disrupt urban life. And cities do not seem to be prepared.

In order to become resilient, cities need to adapt themselves. A first step is awareness of the current vulnerability. How that works becomes visible when looking at the issue of water safety in the 
Netherlands. Living in a low lying country, inhabitants and the government are very well aware of the threat of flooding by the sea and by rivers. Large efforts have been and are still being made to keep the Netherlands safe and adding the future threat of a rising sea level or higher peak levels in the rivers is easily incorporated into the general policy on water safety. Including water nuisance, droughts and heat waves into urban policies seems more complicated, although in recent years there have been more of these incidents than floods. An increased awareness of the widened range of threats within all levels of government and with all stakeholders is a necessary starting point. The Dutch National Delta Program [24] deals with the issue of flooding and also with climate adaptation in urban areas. It is a program on the national level although local governments and water boards are involved. The policy program, however, struggles with climate adaptation in cities, because it is perhaps easy to formulate flooding safety standards on the national scale, but for heat, droughts and water nuisance the most important policies require a local approach.

From the beginning, the Climate Proof Cities research program brought together researchers and governmental representatives and created a community of practitioners. This helped to spread the knowledge the program developed. It also showed how local factors are important in developing a climate adaptation strategy and stimulated practice-oriented research. In the beginning it proved difficult for practitioners to formulate research questions, which meant that researchers were forced to take the first step. Later in the program the collaboration had the healthy tension between the wish of practitioners to have the outcomes here and now, while the researchers insisted on the need to understand better before drawing any conclusion. In the Netherlands, the process of knowledge co-creation in climate adaptation of cities only started with this research project and a longer relation between universities and cities is needed to build up trust on both sides, and the awareness for academia that scientific research is not compromised by this way of working, and for administrations that it pays to embed a researcher for some time in their organisation.

The biggest challenge for increasing resilience lies in existing cities, as the infrastructure, the urban design and the buildings themselves limit the number of possible adaptation measures. But it also poses governance questions on how to use the local windows of opportunity, such as the implementation of reconstruction works or periods of increased awareness of local actors such as housing corporations or citizens themselves. While the CPC program delivered more insight into a large number of possible adaptation options, the question remains how to keep such a relatively weak interest as climate adaptation high on the agenda in order to use occurring opportunities over time. In addition, financing climate adaptation is a practical issue for administrations where, depending on the context, possibilities and limitations, research can help identify new approaches.

The Climate Proof Cities research program resulted from an overarching national research program, similar to programs in the UK and Germany. With national programs coming to an end, there is certainly an issue around the maintenance and continuation of the knowledge base. During the execution of these research programs, national governments may have discovered that increasing urban resilience requires mainly local action, but they should not forget that in a multi-level governance setting, facilitation of research enables this action.

\subsection{Conclusions}

The Climate Proof Cities program has confirmed that urban areas in the Netherlands are vulnerable to a wider range of threats than sea level rise and marine and fluvial flooding only. In times of climate change, the risk of more frequent heat waves, droughts and extreme rainfall events need to be taken into account as they affect human morbidity and mortality, economic damage and result in a less liveable and comfortable urban environment.

The Netherlands is a densely populated country, with most of its population and economic activities concentrated in urban areas. Cities thus constitute the most vulnerable parts of the country. Within cities, the vulnerability varies locally, which creates opportunities for gradually and locally improving the urban environment making use of the "windows of opportunity" provided by the dynamics of a city. Starting the process of increasing resilience now reduces the impacts of weather extremes that will be occurring in the immediate future and solve problems of today.

The Climate Proof Cities program contributed to the body of knowledge on the vulnerability of cities to climate change, and the local factors that characterise the effects. It showed the important role of green infrastructures in the city as they can cool the city as long as water is available for evapotranspiration. It gave more insight in the role of water, which can be cooling as water evaporates, but might also warm the city as stagnant water bodies store heat. The program demonstrated how buildings and streets can be developed in such a way that overheating in buildings can be minimised. In this respect, a relation with climate mitigation (energy saving options) policies is relevant. And the program made clear the importance to bring urban planners and water managers together to reduce water nuisance.

Remaining scientific challenges in supporting climate robust cities are:

- the role of evaporation in the micro-climate of a city;

- monitoring and understanding of precipitation patterns within urban areas;

- understanding the possible role of thermally induced airflow through a city in improving thermal comfort in streets;

- the relation between heat, drought, water availability and the effectiveness of green adaptation measures;

- harmonising information on costs and effectiveness of adaptation options for different climate threats and on different scales;

- integration of approaches for increasing the resilience of vital infrastructures in cities and of the other city systems (including buildings and public spaces);

- options/guidelines for a sustained embedding of climate adaptation in policies of cities and stakeholders, such as housing corporations and infrastructure managers;

- ways to prevent, given the fragmentation of actors and actions, the implementation of suboptimal solutions;

- financing options for adaptation measures and strategies;

- how to develop a sense of urgency with various stakeholders.

\section{Contents of the Special Issue}

The 15 papers in this Special Issue consist of 13 papers submitted by members of the Climate Proof Cities program and 2 papers submitted by other authors. All papers are classified according to five main categories: (1) Urban climate; (2) Sensitivity, impacts, vulnerability; (3) Adaptation measures; (4) Governance; (5) Integration. Papers addressing more than one category have been listed in each of these categories and within each category, papers are listed alphabetically by the last name of the first author.

Papers from the CPC consortium are labelled as such. However, this collection does not provide the complete overview of all results from the CPC program. Other results will be reported in future papers in this and other journals. And finally, it is noted that this Special Issue - as every Special Issue and publication - only provides a 
partial view on a complex problem. Future Special Issues and papers on the topic of climate adaptation in cities are definitely needed.

\subsection{Urban climate}

- Gromke et al. CFD analysis of transpirational cooling by vegetation: Case study for specific meteorological conditions during a heat wave in Arnhem, Netherlands. http://dx.doi.org/10.1016/j. buildenv.2014.04.022 [CPC]

- Jacobs et al. Assessment of evaporative water loss from Dutch cities. http://dx.doi.org/10.1016/j.buildenv.2014.07.005 [CPC]

- Leconte et al. Using local climate zone scheme for UHI assessment: evaluation of the method using mobile measurements. http://dx.doi.org/10.1016/j.buildenv.2014.05.005

- Schrijvers et al. Breakdown of the nighttime urban heat island energy budget. http://dx.doi.org/10.1016/j.buildenv.2014.08.012 [CPC]

- Taleghani et al. Summer thermal comfort within five different urban forms in the Netherlands. http://dx.doi.org/10.1016/j. buildenv.2014.03.014 [CPC]

- Toparlar et al. CFD simulation and validation of urban microclimate: A case study for Bergpolder Zuid, Rotterdam. http://dx. doi.org/10.1016/j.buildenv.2014.08.004 [CPC]

- Van Hove et al. Temporal and spatial variability of urban heat island and thermal comfort within the Rotterdam agglomeration. DOI: http://dx.doi.org/10.1016/j.buildenv.2014.08.029

\subsection{Sensitivity, impacts, vulnerability}

- Cox et al. Simple future weather files for estimating heating and cooling demand. http://dx.doi.org/10.1016/j.buildenv.2014.04.006

- Daanen and Herweijer. Effectiveness of an indoor preparation program to increase thermal resilience in elderly for heat waves. http://dx.doi.org/10.1016/j.buildenv.2014.04.010 [CPC]

- Taleghani et al. Summer thermal comfort within five different urban forms in the Netherlands. http://dx.doi.org/10.1016/j. buildenv.2014.03.014 [CPC]

- Van Hove et al. Temporal and spatial variability of urban heat island and thermal comfort within the Rotterdam agglomeration. DOI: http://dx.doi.org/10.1016/j.buildenv.2014.08.029

\subsection{Adaptation measures}

- Gromke et al. CFD analysis of transpirational cooling by vegetation: Case study for specific meteorological conditions during a heat wave in Arnhem, Netherlands. http://dx.doi.org/10.1016/j. buildenv.2014.04.022 [CPC]

- Jacobs et al. Assessment of evaporative water loss from Dutch cities. http://dx.doi.org/10.1016/j.buildenv.2014.07.005 [CPC]

- Klemm et al. Psychological and physical impact of urban green spaces on outdoor thermal comfort during summer time in the Netherlands. http://dx.doi.org/10.1016/j.buildenv.2014.05.013 [CPC]

- Montazeri et al. Evaporative cooling by water spray systems: CFD simulation, experimental validation and sensitivity analysis. http://dx.doi.org/10.1016/j.buildenv.2014.03.022 [CPC]

- Van Hooff et al. On the predicted effectiveness of climate adaptation measures for residential buildings. DOI: http://dx. doi.org/10.1016/j.buildenv.2014.08.027

- Voskamp and Van de Ven. Planning support system for climate adaptation: composing effective sets of blue-green measures to reduce urban vulnerability to extreme weather events. http:// dx.doi.org/10.1016/j.buildenv.2014.07.018 [CPC]

\subsection{Governance}

- Roders and Straub. Assessment of the likelihood of implementation strategies for climate change adaptation measures in Dutch social housing. http://dx.doi.org/10.1016/j.buildenv.2014. 07.014 [CPC]

\subsection{Integration}

- Groot et al. Integration in urban climate adaptation: Lessons from Rotterdam on integration between scientific disciplines and integration between scientific and stakeholder knowledge. http://dx.doi.org/10.1016/j.buildenv.2014.07.023 [CPC]

\section{Acknowledgements}

The guest editors of the Special Issue, Ronald Albers, Peter Bosch and Bert Blocken want to thank all authors for contributing to this Special Issue. We especially thank Editor-in-Chief prof. QingYan Chen for his support for this Special Issue and for having edited the papers where the handling guest editor Bert Blocken was a co-author. The Climate Proof Cities research program was part of the Dutch Knowledge for Climate program, co-funded by the Ministry of Infrastructure and the Environment, partner cities, water boards and other stakeholders.

\section{References}

[1] IPCC. Summary for policymakers. Climate change 2013: the physical science basis. In: Qin D, Plattner G-K, Tignor M, Allen SK, Boschung J, Nauels A, Xia Y, Bex V, Midgley PM, Stocker TF, editors. Contribution of working group $\mathrm{i}$ to the fifth assessment report of the intergovernmental panel on climate change. Cambridge: Cambridge University Press; 2013.

[2] Revi A, Satterthwaite D, Aragón-Durand F, Corfee-Morlot J, Kiunsi RBR, Pelling M, et al. Urban areas. In: IPCC. Working Group II Contribution to the IPCC Fifth Assessment. Cambridge: Cambridge University Press; 2014.

[3] Rosenzweig C, Solecki W, Hammer SA, Mehrotra S. Climate change and cities: first assessment report of the urban climate change research network. Cambridge: Cambridge University Press; 2011.

[4] World Mayors Council on Climate Change/Mayors Adaptation Forum. 2013. Bonn Declaration of. [Online] 29.04.14, http://resilient-cities.iclei.org/index. php?id=833.

[5] Durban Adaptation Charter, http://www.durbanadaptationcharter.org/home, Retrieved on 29.04.14.

[6] de Wilde P, Coley D. The implications of a changing climate for buildings. Build Environ 2012;55:1-7.

[7] Oke TR. Boundary layer climates. 2nd ed. London: Methuen; 1987.

[8] Oke TR. IOM Report No. 81, WMO=TD No. 1250. 06.05.14. Initial guidance to obtain representative meteorological observations at urban, vol. 2006; 2006. http://www.wmo.int/pages/prog/www/IMOP/publications/IOM-81/IOM-81UrbanMetObs.pdf.

[9] Rizwan AM, Dennis YCL, Liu C. A review on the generation, determination and mitigation of the urban heat island. J Environ Sci - China 8, 2008;20(1): 120-8.

[10] Steeneveld GJ, Koopmans S, Heusinkveld BG, van Hove LWA, Holtslag AAM Quantifying urban heat island effects and human comfort for cities of variable size and urban morphology in the Netherlands. J Geophys Res - Atmos 2011;116:D20129.

[11] van Hove LWA, Jacobs CMJ, Heusinkveld BG, Elbers JA, van Driel, Holtslag AAM. Temporal and spatial variability of urban heat island and thermal comfort within the Rotterdam agglomeration. Build Environ 2015;83: 91-103.

[12] Slingerland J. Mitigation of the urban heat island effect by using water and vegetation. PhD thesis. Delft University of Technology; 2012.

[13] van Hove LWA, Jacobs CMJ, Heusinkveld BG, Elbers JA, Steeneveld GJ Koopmans S, et al. Exploring the urban heat island intensity of Dutch cities. In: Jankovic V, Webb B, Hebbert M, editors. City weathers, meteorology and urban design 1950-2010. Manchester Architecture Research Centre, University of Manchester; 2011.

[14] Wolters D, Brandsma T. Estimating the urban heat island in residential areas in the Netherlands using observations by weather amateurs. J App Meteorol Climatol 2012;51:711-21.

[15] Klok EJ, Duyzer J, Schaminee S, Mauri E. Urban heat islands in the Netherlands retrieved from satellite images. 2012. TNO report TNO-060-UT-2012-01117.

[16] Grimmond CSB. Urbanization and global environmental change: local effects of urban warming. Geogr J 2007;173:83-8. 
[17] van Hooff T, Blocken B. Coupled urban wind flow and indoor natural ventilation modelling on a high-resolution grid: a case study for the Amsterdam ArenA stadium. Environ Model Softw 2010;25(1):51-65.

[18] van Hooff T, Blocken B. On the effect of wind direction and urban surroundings on natural ventilation of a large semi-enclosed stadium. Comput Fluids 2010;39:1146-55.

[19] Toparlar Y, Blocken B, Vos P, van Heijst GJF, Janssen WD, van Hooff T, et al. CFD simulation and validation of urban microclimate: a case study for Bergpolder Zuid, Rotterdam. Build Environ 2015;83:79-90.

[20] Gromke CB, Blocken B, Janssen WD, Merema B, van Hooff T, Timmermans HJP. CFD analysis of transpirational cooling by vegetation: case study for specific meteorological conditions during a heat wave in Arnhem, Netherlands. Build Environ 2015;83:11-26.

[21] Heusinkveld BG, Steeneveld GJ, van Hove LWA, Jacobs CMJ, Holtslag AAM. Spatial variability of the Rotterdam urban heat island as influenced by urban land use. J Geophys Res 2014;119(2):677-92.

[22] Höppe P. The physiological equivalent temperature - a universal index for the biometeorological assessment of the thermal environment. Int J Biometeorol 1999;43:71-5.

[23] van den Hurk B, Klein Tank AK, Lenderink G, van Ulden A, van Oldenborgh G], Katsman C, et al. New climate change scenarios for the Netherlands. Water Sci Technol 2007;56(4):27-33.

[24] Ministry of Infrastructure and Environment, Ministry of economic Affairs. Deltaprogram 2014, Working on the Delta, http://www.deltacommissaris.nl/ english/Images/Delta\%20Program\%202014_English_tcm310-, Retrieved on 29.06.13.

[25] Stone K, Daanen H, Jonkhoff W, Bosch P. Quantifying the sensitivity of our urban systems - Impact functions for urban systems. 2013. Deltares report 1202270.008

[26] Oven K, Curtis S, Reaney S, Riva M, Stewart MG, Ohlemuller R, et al. Climate change and health and social care: defining future hazard, vulnerability and risk for infrastructure systems supporting older people's health care in England. Appl Geogr 2012;33:16-24.

[27] Carter JG, Connelly A, Handley J, Lindley S. European cities in a changing climate: exploring climate change hazards, impacts and vulnerabilities. The University of Manchester, Centre for Urban and Regional Ecology 2012.

[28] Huynen MMTE, Martens P, Schram D, Weijenberg MP, Kunst AE. The impact of heat waves and cold spells on mortality rates in the Dutch population. Environ Health Perspect 2001;109:463-70.

[29] Garssen J, Harmsen C, De Beer J. The effect of the summer 2003 heat wave on mortality in the Netherlands. Eurosurveillance 2005;10:165-7.

[30] Brücker G. Vulnerable populations: lessons learnt from the summer 2003 heat waves in Europe. Euro Surveill 2005;10:147.

[31] Kovats RS, Hajat S. Heat stress and public health: a critical review. Annu Rev Public Health 2008;29:41-55.

[32] Daanen HAM, Heusinkveld B, Hove B, Riet N. Heat strain in elderly during heat waves in the Netherlands. In: Koskolou M, Kounalakis S, editors. Abstract Book XIV International Conference on Environmental Ergonomics, Vol 2011; 2011. p. 168-70.

[33] Daanen HAM, Herweijer JA. Effectiveness of an indoor preparation program to increase thermal resilience in elderly for heat waves. Build Environ 2015;83: 115-9.

[34] Seppanen O, Fisk WJ, Faulkner D. Control of temperature for health and productivity in offices. 2004. Report NBNL-55448.

[35] van Hooff T, Blocken B, Hensen JLM, Timmermans HJP. On the predicted effectiveness of climate change adaptation measures for residential buildings. Build Environ 2014:82:300-16.

[36] Van der Hoeven F, Wandl A. Amsterwarm: mapping the landues, health and energy-efficiency implications of the Amsterdam urban heat island. Sage; June 24, 2014. Building Serv Eng Res Technol.

[37] Van de Ven F, van Nieuwkerk E, Stone K, Veerbeek W, Rijke J, van Herk S, et al. Building the Netherlands climate proof: urban areas, ISBN 978-94-9007-0472. KvK report nr 042/2011, KvR report nr036/2011.

[38] Luijendijk E. Als een paal boven water...Een onderzoek naar technische en economische gevolgen van wisselende grondwaterstanden voor oud stedelijk gebied. Houten: Grontmij; 2006.

[39] Bosch PR, Hoogvliet M, Goosen H, Van der Hoeven F. Fysieke bouwstenen voor de knelpuntenanalyse nieuwbouw en herstructurering. 2011. rapport nr. TNO-060-UT-2011-01826.

[40] Crawly DB, Lawrie LK, Winkelmann FC, Buhl WF, Juang YJ, Pedersen CO, et al EnergyPlus: creating a new-generation building energy simulation program. Energy Build 2001;33(4):319-31.

[41] Crawly DB, Hand JW, Kummert M, Griffith BT. Contrasting the capabilities of building energy performance simulation programs. Build Environ 2008;43(4):674-85.

[42] Hensen JLM, Lamberts R, Negrao COR. A view of energy and building performance simulation at the start of the third millenium. Energy Build 2002;34(9):853-5.

[43] Chen Q. Ventilation performance prediction for buildings: a method overview and recent applications. Build Environ 2009;44(4):848-58.

[44] Ramponi R, Blocken B. CFD simulation of cross-ventilation for a generic isolated building: impact of computational parameters. Build Environ 2012;53: 34-48.
[45] Murakami S. Current status and future trends in computational wind engineering. J Wind Eng Ind Aerodyn 1997;67 and 68:3-34.

[46] Franke J, Hellsten A, Schlünzen H, Carissimo B, editors. Best practice guideline for the CFD simulation of flows in the urban environment. Brussels: COST Office; 2007, ISBN 3-00-018312-4.

[47] Blocken B, Stathopoulos T, Carmeliet J, Hensen JLM. Application of CFD in building performance simulation for the outdoor environment: an overview. J Build Perform Simul 2011;4(2):157-84

[48] Moonen P, Defraeye T, Dorer V, Blocken B, Carmeliet J. Urban physics: effect of the microclimate on comfort, health and energy demand. Front Archit Res 2012;1(3):197-228.

[49] Tominaga Y, Stathopoulos T. CFD simulation of near-field pollutant dispersion in the urban environment: a review of current modelling techniques. Atmos Environ 2013;79:716-30.

[50] Blocken B. 50 years of computational wind engineering: past, present and future. J Wind Eng Ind Aerodyn 2014;129:69-102.

[51] Taleghani M, Kleerekoper L, Tenpierik M, van den Dobbelsteen A. Outdoor thermal comfort within five different urban forms in the Netherlands. Build Environ 2015;83:65-78.

[52] Montazeri H, Blocken B, Hensen JLM. Evaporative cooling by water spray systems: CFD simulation, experimental validation and sensitivity analysis. Build Environ 2015;83:129-41.

[53] Schrijvers PJC, Jonker HJJ, Kenjeres S, de Roode SR. Breakdown of the nighttime urban heat island energy budget. Build Environ 2015;83:50-64.

[54] Vergroesen T, Brolsma R, Tollenaar D. Verwerking van extreme neerslag in stedelijk gebied. 2013. Deltares report 1202270-009.

[55] Klemm W, Heusinkveld BG, Lenzholzer S, Jacobs MH, van Hove B. Psychological and physical impact of urban green spaces on outdoor thermal comfort during summertime in the Netherlands. Build Environ 2015;83:120-8.

[56] Wong NH, Chen Y, Ong CL, Sia A. Investigation of thermal benefits of rooftop garden in the tropical environment. Build Environ 2003;38:261-70.

[57] Dimoudi A, Nikolopoulou M. Vegetation in the urban environment: microclimatic analysis and benefits. Energy Build 2003;35:69-76.

[58] Alexandri E, Jones P. Temperature decreases in an urban canyon due to green walls and green roofs in diverse climates. Build Environ 2008;43: 480-93.

[59] Wong NH, Kwang Tan AY, Chen Y, Sekar K, Tan PY, Chan D, et al. Thermal evaluation of vertical greenery systems for building walls. Build Environ 2010;45: $663-72$

[60] Bowler DE, Buyung-Ali L, Knight TM, Pullin AS. Urban greening to cool towns and cities: a systematic review of the empirical evidence. Landsc Urban Plan 2010;97(3):147-55.

[61] Brolsma R, Boderie P, de Graaf M, Bonte M, Brand R, de Wit J, et al. Combining water and energy supply. Deltares; 2013. p. 1202270-3016.

[62] Uittenbroek CJ, Janssen-Jansen LB, Runhaar HAC. Mainstreaming climate adaptation into urban planning: overcoming weaknesss, seizing opportunities and evaluating the results in two Dutch case studies. Reg Environ Change 2013;13(2).

[63] McCarney PL. City indicators on climate change: implications for policy leverage and governance. In: Marseilles. World Bank's 5th urban research Symposium; 2009.

[64] Uittenbroek CJ, Janssen-Jansen LB, Spit TJM, Salet WGM, Runhaar HAC. Political committment in organizing municipal responses to climate adaptation: the dedicated approach versus the mainstreaming approach. Environ Polit 2014. http://dx.doi.org/10.1080/09644016.2014.920563.

[65] Meerkerk I, van Boonstra, B, Edelenbos J. Self-organization in urban regeneration - a two case comparative research. Eur Plan Stud 2013;21: $1630-52$.

[66] Roders MJ, Straub A, Visscher HJ. The central role of the construction sector for climate change adaptions in the built environment. In: Proceedings of the 19th CIB World Building Congress: Construction and Society, Brisbane, Australia, 5-9 May 2013; 2013.

[67] Groot AME, Bosch PR, Buijs S, Jacobs CMJ, Moors EJ. Integration in urban climate adaptation: lessons from Rotterdam on integration between scientific disciplines and integration between scientific and stakeholder knowledge. Build Environ 2015:83:177-88.

R.A.W. Albers*, P.R. Bosch TNO, P.O. Box 80015, 3508 TA Utrecht, The Netherlands

B. Blocken

Department of the Built Environment, Eindhoven University of Technology, P.O. Box 513, 5600 MB, The Netherlands

Department of Civil Engineering, Leuven University, Kasteelpark Arenberg 40 - Bus 2447, 3001 Leuven, Belgium

A.A.J.F. van den Dobbelsteen

Department of Architectural Engineering and Technology, Delft University of Technology, P.O. Box 5043, 2600 GA Delft, The Netherlands 
L.W.A. van Hove

Meteorology and Air Quality, Wageningen University, PO Box 47, 6700AA Wageningen, The Netherlands

T.J.M. Spit

Faculty of Geosciences, Utrecht University, Heidelberglaan 2, 3584 CS Utrecht, The Netherlands

F. van de Ven

Urban Land and Water Management, Deltares, Princetonlaan 6, 3584

CB Utrecht, The Netherlands

Department Water Management, Delft University of Technology, PO-box 5048, 2600 GA Delft, The Netherlands
T. van Hooff Department of the Built Environment, Eindhoven University of Technology, P.O. Box 513, 5600 MB, The Netherlands

$\mathrm{V}$. Rovers

TNO, P.O. Box 80015, 3508 TA Utrecht, The Netherlands

* Corresponding author. E-mail address: ronald.albers@tno.nl (R.A.W. Albers).

Available online 18 September 2014 